one series was found to be an important cause of anaphylactic shock. ${ }^{1}$ As anaphylaxis has not been reported with chloral hydrate the phenazone component was probably responsible for the reaction in our patient.

This case also illustrates the importance of reporting even the most unlikely drug reaction when no other satisfactory explanation can be found.

1 Torok, H, Dermatologia Internationalis, 1969, 2, 57.

(Accepted 19 August 1977)

Hillingdon Hospital, Uxbridge, Middlesex UB8 3NN

STEVEN PERL, MB, MRCP, medical registrar

\section{Sulphasalazine-induced lupus syndrome in ulcerative colitis}

We repo, there a patient who developed a lupus syndrome while receiving sulphasalazine. Although early reports recognised that sulphonamides could induce systemic lupus erythematosus (SLE), ${ }^{1}$ later ones have implicated other drugs such as hydrallazine and procainamide. Sulphasalazine, which is widely used in maintenance treatment of ulcerative colitis, is split by colonic bacteria into sulphapyridine and 5-aminosalicylic acid. The sulphonamide moiety is absorbed, and higher blood concentrations of sulphapyridine are attained in patients who are of "slow-acetylator" phenotype."

\section{Case report}

In 1969 a 52-year-old woman developed increased frequency of bowel action, with associated loose stools containing mucus and blood. She had previously been well, apart from having undergone a thyroidectomy for thyrotoxicosis at the age of 21 . One of her sons had had extensive ulcerative colitis since 1965 and had developed a hypersensitivity rash to sulphasalazine. She was also diagnosed as having ulcerative colitis and was treated with sulphasalazine until 1971 without apparent adverse effect. She was first seen by us in March 1972 when her symptoms had worsened. Sigmoidoscopy, recta biopsy, and barium-enema examination confirmed active ulcerative colitis extending to the hepatic flexure, and treatment with sulphasalazine, $2 \mathrm{~g} /$ day was started. Her symptoms remained troublesome, however, and prednisolone, $15 \mathrm{mg} /$ day, was introduced in April 1972. The dose was gradually reduced, and the drug was discontinued in April 1974

She remained in remission on sulphasalazine, $3 \mathrm{~g} /$ day, but began to complain of joint pains, and by October 1974 she had developed a non-deforming arthritis with active synovitis of shoulders, wrists, metacarpophalangeal joints, proximal interphalangeal joints, and metatarsophalangeal joints. Bilateral knee effusions were also present. Treatment with ibuprofen, $1 \cdot 2$ g/day, was started, but the arthritis failed to improve. At this stage rheumatoid factor and antinuclear antibodies (ANA) were absent from the serum, but by January 1975 she had begun to develop Raynaud's phenomenon, and by June ANA were present in high titres with a homogeneous pattern. DNA antibody concentrations were raised $(190 \mathrm{U} / \mathrm{ml}$ (normal: $<25 \mathrm{U} / \mathrm{ml})$ ) differential agglutination titres, tests for LE cells (performed on four occasions), and anti-smooth-muscle and antimitochondrial antibodies gave negative results; $\mathrm{C} 3, \mathrm{C} 4$, and $\mathrm{CH}_{50}$ values were normal; tissue-typing showed the presence of histocompatibility antigens HLA-A1, - A3, -B7, and -B8.

We thought that her illness might be a drug-induced lupus syndrome, so sulphasalazine was stopped in August 1975. The arthritis remained active, however, and in October 1975 she also had digital vasculitic lesions, although by January 1976 both of these conditions were resolving. During the acute illness her serum contained a mixed-component cryoglobulin, and ${ }^{125} \mathrm{I}-\mathrm{Clq}$ binding activity ${ }^{3}$ was increased. This suggested the presence of circulating immune complexes, although renal and liver function test results, and muscle enzyme values were normal. Radiographs showed some small "hook" erosions in the metacarpophalangeal joints, similar to those seen in a Jaccoud arthropathy. ${ }^{4}$

Levels of DNA binding activity and ANA titres remained high for six months after sulphasalazine was stopped, but then fell to normal (fig 1) As the polyarthritis regressed the ulcerative colitis became more active, and maintenance treatment with prednisolone enemas $20 \mathrm{mg}$ nightly proved ineffective. She refused to take systemic steroids, and in April 1976 azathioprine treatment was begun, but was discontinued after a month because of persistent nausea and vomiting. In May 1976 sulphasalazine, $3 \mathrm{~g} /$ day, was

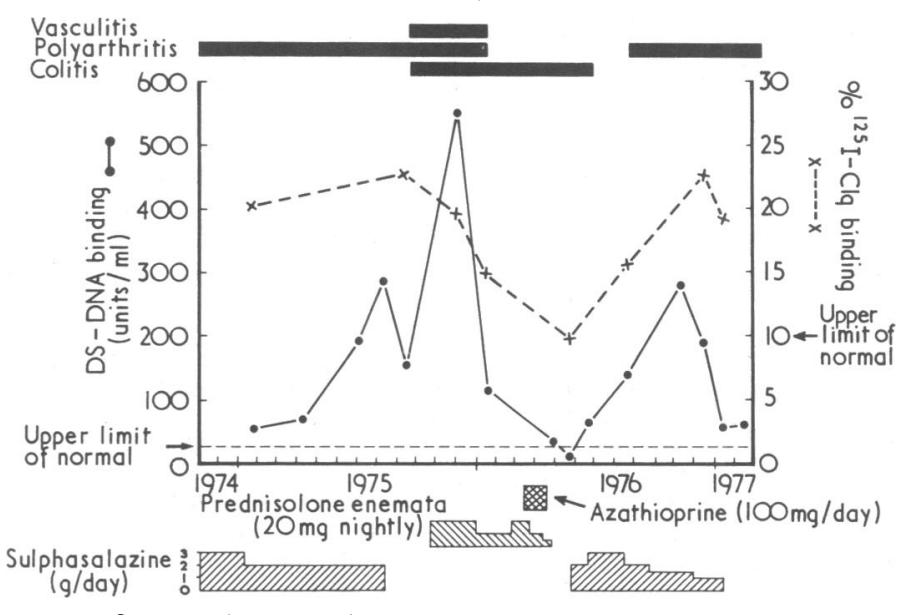

FIG 1-Sequential study of clinical features (top), treatment (bottom), and changes in binding activity of double-stranded DNA (DS-DNA) and radioiodinated $\left({ }^{125} \mathrm{I}\right)$ complement $(\mathrm{Clq})$.

reintroduced, with subsequent improvement of bowel symptoms. After two months, however, she again developed symptoms of active arthritis and synovitis, the DNA binding activity increased, and tests for ANA gave positive results. Sulphasalazine dosage was gradually reduced to $1 \mathrm{~g} /$ day, but joint symptoms persisted, and the drug was again withdrawn in January 1977.

Pharmacokinetics-Serum sulphapyridine concentration, measured when the patient was taking sulphasalazine, $2 \mathrm{~g} /$ day, was $213 \mu \mathrm{mol} / 1(53 \mu \mathrm{g} / \mathrm{ml})$ (normal range: $80-201 \mu \mathrm{mol} / 1(20-50 \mu \mathrm{g} / \mathrm{ml})$ ). Her acetylator phenotype for sulphadimidine was determined ${ }^{5}$ a week after sulphasalazine had been withdrawn, and she was shown to be a slow acetylator.

Anti-DNA antibodies-Sera from 24 unselected patients with ulcerative colitis or Crohn's disease, who did not have joint symptoms, and who were on long-term treatment with sulphasalazine, $1-3 \mathrm{~g} /$ day, were tested for DNA binding activity. All had antibody concentrations within the normal range.

\section{Comment}

Although the patient did not fulfil the American Rheumatism Association's criteria ${ }^{6}$ for the diagnosis of SLE, she showed several features of a lupus syndrome while taking sulphasalazine-for example, polyarthritis, Raynaud's phenomenon, and vasculitis. High concentrations of ANA and abnormalities of DNA binding activity remitted when the drug was discontinued, but recurred when it was reintroduced-we therefore considered that the syndrome was druginduced. The improvement after withdrawal of sulphasalazine in 1975 may have been due to the subsequent administration of prednisolone enemas, which are known to produce systemic effects.? Nevertheless, the fall in DNA binding activity that occurred in 1976 was not associated with any change in treatment other than the reduction of the sulphasalazine dose.

Antibodies in patients with drug-induced SLE are usually directed against DNA nucleoprotein or single-stranded $\mathrm{DNA}^{8}$, and antibodies to DNA nucleoprotein are responsible for the finding of LE cells in such patients. Our patient is unusual in that antibodies against a wellcharacterised double-stranded DNA antigen ${ }^{9}$ were detected in high titres in the absence of LE cells. Our survey of other patients receiving sulphasalazine does not suggest that the presence of such antibodies is commonly associated with administration of this drug. Interestingly, changes in ${ }^{125} \mathrm{I}-\mathrm{Clq}$ binding activity followed the same general pattern as changes in DNA antibody concentrations, suggesting that the DNA antibodies may have been partly responsible for the formation of circulating immune complexes. The absence of clinical evidence of renal disease in a patient with circulating DNA antibodies and immune complexes may seem surprising, but serum complement concentrations in our patient were consistently normal, and renal complications in SLE are more often seen in patients with hypocomplementaemia. ${ }^{10}$ Our patient's digital vasculitic lesions suggested that the circulating complexes had localised in medium-sized arteries, and this, in the absence of renal disease, suggested that the complexes were very large. ${ }^{11}$

Alarcón-Segovia et al ${ }^{12}$ reviewed possible associations between chronic ulcerative colitis, SLE, and the presence of LE cells. In several of their cases the now well-recognised association between ulcerative colitis and chronic active hepatitis in the presence of LE cells occurred. Four patients on sulphasalazine, however, developed arthropathy, polyserositis, and haematological abnormalities with positive test 
results for LE cells. These abnormalities resolved on stopping the drug, and the authors suggested that sulphonamides might unmask a latent "lupus diathesis" in certain patients with ulcerative colitis. The HLA-B8 antigen is associated with various immunologically mediated diseases, ${ }^{13}$ and it may have predisposed our patient to develop a drug-induced lupus syndrome.

This case highlights the possibility of a sulphonamide-induced SLE syndrome occurring in any patient with colitis who develops polyarthropathy or vasculitis while receiving sulphasalazine. The patient's slow-acetylator phenotype permitted the development of high serum concentrations of sulphapyridine, even with modest doses of sulphasalazine, and this may have facilitated the appearance of the lupus-like syndrome.

We thank Dr R N Maini and Dr R A Parkins for permission to publish this case and for helpful criticism, and Ms P Mumford for performing the ${ }^{125} \mathrm{I}-\mathrm{Clq}$ binding assay.

${ }^{1}$ Gold, S, Lancet, 1951, 1, 268.

2 Das, K M, et al, Gut, 1973, 14, 631.

${ }^{3}$ Nydegger, U E, et al, fournal of Clinical Investigation, 1974, 54, 297.

${ }^{4}$ Bywaters, E G L, British Heart fournal, 1950, 12, 101.

${ }^{5}$ Evans, D A P, et al, fournal of Medical Genetics, 1972, 9, 53.

${ }^{6}$ Cohen, A S, et al, Bulletin on Rheumatic Diseases, 1971, 21, 643.

'Powell-Tuck, J, et al, British Medical fournal, 1976, 1, 193.

${ }^{8}$ Winfield, J B, and Davis, J S, Arthritis and Rheumatism, 1974, 17, 97.

${ }^{9}$ Holian, J, et al, Annals of the Rheumatic Diseases, 1975, 34, 438.

${ }^{10}$ Schur, P H, and Sandson, J, New England Fournal of Medicine, 1968, 278, 533 .

${ }^{11}$ Levinsky, R J, Cameron, J S, and Soothill, J F, Lancet, 1977, 1, 564

12 Alarcón-Segovia, D, et al, Gut, 1965, 6, 39.

${ }^{13}$ Bach, F H, and Van Rood, J J, New England fournal of Medicine, 1976, 295, 927.

(Accepted 19 August 1977)

\section{Charing Cross Hospital, London W6}

I D GRIFFITHS, $\mathrm{MB}$, MRCP, senior registrar, department of rheumatology S P KANE, MA, MRCP, senior registrar, department of gastroenterology

\section{Stevens-Johnson syndrome due to rifampicin}

The recorded side effects of rifampicin include nausea, skin rashes, liver dysfunction, hypersensitivity reactions, leucopenia, thrombocytopenia, and ocular abnormalities. ${ }^{12}$ We report a case of overt Stevens-Johnson syndrome apparently caused by rifampicin.

\section{Case report}

An African man of about 40 years of age was diagnosed as having pulmonary tuberculosis, and started on a regimen of rifampicin $600 \mathrm{mg}$, streptomycin $1 \mathrm{~g}$ intramuscularly, and isoniazid $300 \mathrm{mg}$ daily. He made little clinical improvement, however, and after four weeks ethambutol $800 \mathrm{mg}$ daily was added. One week later he developed severe exfoliative dermatitis, buccal ulceration, blepharoconjunctivitis, and anterior uveitis. He was feverish and extremely ill. All antituberculous drugs were stopped, and he was treated with high doses of oral prednisolone with local steroid applications to the eyes and skin. He improved slowly, and three weeks later was considered well enough to have the antituberculous drugs reintroduced one at a time. Rifampicin alone was started, but four days later he once again began to develop dermatitis, buccal ulceration, and conjunctivitis similar to his previous condition. The rifampicin was promptly stopped and steroids begun again. He improved quickly, and streptomycin, isoniazid, and ethambutol were added stepwise with no further complications.

\section{Comment}

The recurrence of Stevens-Johnson syndrome in our patient after the reintroduction of rifampicin strongly suggests a causal relation. Interestingly, the patient tolerated the first four weeks of rifampicin treatment, but became ill one week after the addition of ethambutol. Lees et $\mathrm{al}^{3}$ have recorded a case of ocular side effects in a patient on rifampicin and ethambutol. Thus ethambutol may act as a triggerfactor to the toxic effects of rifampicin.

${ }^{1}$ Martindale: The Extra Pharmacopoeia, ed N W Blacow and A Wade, 26th edn, p 1416. London, Pharmaceutical Press, 1972.

${ }^{2}$ Cayley, F E, and Majumdar, S K, British Medical fournal, 1976, 1, 199.

${ }^{3}$ Lees, A W, et al, Tubercle, 1971, 52, 182.

(Accepted 31 August 1977)

Konkola Mine Hospital, PO Box 1, Chililabombwe, Zambia

RAYMOND NYIRENDA, BSC, $\mathrm{MB}$, medical officer

GEOFFREY V GILL, MRCP, DTM\&H, consultant physician

\section{Severe anaphylactoid reactions to dextran 70}

We report two cases of anaphylactoid reactions to dextran 70 in asthmatic patients. After vigorous resuscitation one patient recovered completely but the other died.

\section{Case reports}

Case 1-This patient, a 24-year-old primigravida, had suffered from asthma since the age of 3 , for which she used a salbutamol sulphate inhaler (Ventolin), and took Franol tablets (ephedrine hydrochloride $11 \mathrm{mg}$, theophylline $120 \mathrm{mg}$, phenobarbitone $8 \mathrm{mg}$ ). She was delivered 19 days preterm by elective lower-segment caesarean section, the indications being fetal tachycardia of 180 beats/min and moderately severe pre-eclampsia. Her blood pressure had risen from $110 / 70 \mathrm{~mm} \mathrm{Hg}$ at admission to $140 / 100$ $\mathrm{mm} \mathrm{Hg}$ four days before operation. After the caesarean section her systolic blood pressure fell to a level of $60-70 \mathrm{~mm} \mathrm{Hg}$. Dextran 70 (Lomodex 70, Fisons) was infused intravenously, and she developed severe bronchospasm and a florid urticarial rash on her limbs. Dextran 70 infusion was replaced with compound sodium lactate injection immediately The bronchospasm failed to respond to intravenous aminophylline $(150 \mathrm{mg})$, but responded to intravenous salbutamol sulphate $(0.5 \mathrm{mg})$. Her subsequent recovery and her puerperium were uneventful.

Case 2-A 25-year-old woman (gravida 2, para 1) with bronchial asthma and on treatment with prednisolone, beclomethasone dipropionate, salbutamol sulphate, and sodium cromoglycate (Intal) was admitted to the labour ward from the antenatal ward, where she had been for two weeks because of mild pre-eclampsia, in early labour. She was given $100 \mathrm{mg}$ hydrocortisone intramuscularly as the first dose of cover in labour. Labour was accelerated by amniotomy, an infusion of $5 \%$ dextrose was started, and epidural analgesia instituted using bupivacaine hydrochloride (Marcain) because the patient's blood pressure was varying between $140 / 90 \mathrm{~mm} \mathrm{Hg}$ and $150 / 100$ $\mathrm{mm} \mathrm{Hg}$. Ten minutes later her blood pressure dropped to $90 / 69 \mathrm{~mm} \mathrm{Hg}$, so an intravenous dextran 70 (Lomodex 70, Fisons) infusion was started. After $200 \mathrm{ml}$ had been infused for 10 minutes her blood pressure became unrecordable, she complained of tightness in the chest, and within one minute she became cyanosed and pulseless. Vigorous resuscitation was started with cardiac massage; oxygen $100 \%$ was given through an endotracheal tube, using intermittent positive-pressure ventilation; intravenous adrenaline $0.1 \mathrm{mg}$, hydrocortisone $400 \mathrm{mg}$, sodium bicarbonate infusion, and aminophylline $250 \mathrm{mg}$ were given. During resuscitation the heart went into asystole and ventricular fibrillation several times and was defibrillated about a dozen times. Resuscitation was stopped after 80 minutes. The main problem during attempted resuscitation was severe bronchospasm, making it impossible to ventilate the lungs properly. Necropsy examination (performed by Professor H L Sheehan) showed subdiaphragmatic oedema, congestion of gastric mucosa and of kidneys, and incoagulability of the blood. Amniotic fluid embolism was excluded by gross and microscopical examination of the lungs and other organs. There were no pathological changes related to the history of asthma.

\section{Comment}

The number of hypersensitivity reactions ${ }^{1-5}$ (ranging from mild urticaria to anaphylactoid reactions) reported to Fisons Ltd, manufacturers of dextran 70 (Lomodex 70), which we used in the above two cases, was one per 22852 bottles sold during 1972-6. Thirty-five per cent of the patients who developed hypersensitivity to dextran 70 had a history of bronchial asthma and $17 \%$ had a history of allergy (Fisons Ltd, personal communication). 